\title{
Legal Protection of State Assets in the Supreme Court (MA)
}

\author{
Rosfiana $^{1}$, Evita Isretno Israhadi ${ }^{2}$ \\ Student Program Doctor of Law Borobudur University, Jl. Pemuda, RT.1/RW.3, \\ Rawamangun, Kec. Pulo Gadung, DKI Jakarta 13220, Indonesia ${ }^{1,2}$ \\ \{rosfiana.kamil.rf@gmail.com ${ }^{1}$, evita_isretno@borobudur.ac.id² ${ }^{2}$,
}

\begin{abstract}
Asset protection is the responsibility of a public institution. The Supreme Court (MA), as the highest court in Indonesia, must protect its assets. This paper uses a normative juridical approach. As part of the law's application in cassation and review so that all rules and regulations in all country regions can be applied relatively, appropriately and correctly, legal protection is required for the Supreme Court's assets. This paper concludes that there is a need for legal protection for asset management in the Supreme Court (MA) and protection against cassation evidence at the highest state court level.
\end{abstract}

Keywords: Legal Protection; State Assets; Supreme Court

\section{Introduction}

The law is not just to realize order; more than that, the law must provide a sense of justice for the community. The law will not give birth to justice, but it must be enforced to achieve the law's existence. Law enforcement's function is to actualize the law's rules following the law's wishes, namely to realize human attitudes or behaviour following the frame (framework) that a Law or law has established. A law enforcement system with good values is about the harmony between values with rules and natural human behaviour. The law is interested in ensuring the community's social life because there is an interest in law and society. The criminal justice system must always promote the interests of law and justice. Whatever the theory of justice is used, the definition of justice must include honesty, impartiality, and proper sanctioning and reward.

State Assets are all forms of living and non-living assets in tangible or intangible or intangible objects, movable or immovable, controlled and owned by the State. The subject of controlled State assets is in the form of potential State assets divided into agrarian/land, agriculture, plantation, forestry, mining, minerals, coal, oil and gas, marine and fisheries, and water resources, air and space, energy. Geothermal, other State assets. Regulated in sectoral laws. The minister of finance as a fiscal manager and the minister/head of the institution as a sectoral manager.

The subjects of State assets owned are state / regional property, namely tangible goods, intangible goods, movable goods, immovable goods originating from purchases or acquisitions at the expense of APBN/D and other legitimate additions. Minister of finance as manager of state property and governor/regent/mayor as manager of the regional property and 
minister/head of institution as users of state property and goods/regions. in BUMN / D, State assets in other legal entities, and State assets at international institutions. The Minister of Finance is the representative of the central government in the ownership of regional State assets and the Minister of BUMN as BUMN shareholders' proxy. The difference is the ownership and the scale allowed. BUMN is state-owned and can operate throughout Indonesia to conduct its business, while BUMD is owned by a particular area and is separated from regional assets. BUMD may carry out its activities in its home region or another place with a provincial government's cooperation permit. Both are companies whose entire or the State holds most of their capital (BUMN) or territory (BUMD). They also come in various forms. Even though the aim is to make a profit, goods or services issued by BUMN / BUMD usually have a lower price compared to other parties. This is intended to help the people.

Management of state assets (assets) is one of the Ministry of Finance's functions as State General Treasurer (BUN). The management of state assets as a function at the Ministry of Finance developed significantly after its position was entirely dedicated in an echelon I level unit, namely the Directorate General of State Assets (DJKN), in 2006. And functionally, its mature form has been accommodated in article 28, Presidential Regulation Number 28 of 2015 , in which the scope of state assets being managed includes state property (BMN), separated state assets (KND), and assets of other countries (KNL). Apart from carrying out the state assets' function, DJKN also carries out an appraisal, management of state receivables, and auction services. Based on the Strategic Plan of the Ministry of Finance, 2015 s.d. In 2019 , in terms of value, the potential for assets owned by the government was tremendous. This can be seen from the value of state-owned goods (BMN) in the form of fixed assets which has increased significantly, from the value of BMN as of December 31, 2005, of IDR 237.78 trillion, in 2014 it had reached IDR 1,796.73 trillion (Semester I LKPP 2014). Then for the assets of other countries, it was recorded at Rp. 191.38 trillion. Also, state assets in government investment (separated state assets) have no less total value.

As one of the high state institutions in the judiciary, the Supreme Court has assets that are also part of state-owned holdings, so that it is necessary to protect it legally. In the future, the challenges related to state-owned assets at the Supreme Court will undoubtedly be heavier. It requires better legal protection instruments in terms of structuring and procurement of goods at the Supreme Court.

\section{Methods}

The approach used in this study is normative juridical, namely studying and reviewing legal principles, especially favourable legal rules derived from existing literature materials from legislation and other provisions primarily related to the management of State Property.

\section{Discussion}

\subsection{Legal Protection of State Assets}

With the BMN inventory and assessment steps, it is projected that in the future, an accurate and reliable BMN database will be created so that it can be used for planning needs and budgeting for goods or capital expenditures in ministries/state institutions. 
The management of state property is a very strategic and vital function. Viewed from a political point of view, this is directly related to the embodiment of people's sovereignty to protect all spilt blood and homeland of Indonesia, namely that every inch of the territory of the Republic of Indonesia must be guarded and maintained so that it does not fall into the hands of outsiders. Meanwhile, from a fiscal point of view, the management of state property/wealth must be our common concern, that almost $80 \%$ of the composition of our country's assets/assets is in the form of fixed assets (land and buildings), where in the last few years LKPP still becomes a problem and the spotlight of the external government auditor (BPK) in providing an opinion.

Whereas nearly $90 \%$ of state assets have not been managed professionally, state assets have not been properly and adequately inventoried, resulting in poor quality Financial Statements of these state institutions. The role of the Minister of Finance as BUN, especially concerning duties as Property Manager (in this case represented by the Directorate General of State Wealth / DJKN) as a figure for a vital organization, is at the forefront of realizing best practices in the management of state property/assets which until now it is still not well organized, so it is hope that this will be able to answer the question "how much is the actual value of the assets/wealth of the Indonesian people, which stretches from the tip of Sabang to Merauke?

It must be admitted that managing the assets/wealth of this country is not as easy as turning your palms, considering that since the independence that gave birth to the Unitary Republic of Indonesia until now, it is not certain (accurately) the amount of this nation's wealth. The management of state property is still not a priority for policymakers to handle when compared to budget management (money). Control of state property that is professional and modern by prioritizing good governance is expected to increase the trust and recognition of outsiders for the bureaucratic reform that is being echoed by the government so that the government's image in international institutions' eyes donors will improve.

The Ministry of Finance manages the legal protection of state assets. It is a regulation in Law No. 17 of 2003 concerning State Finance. Of course, the law is strong enough that asset management in this state ministry/institution already has permanent legal force.

\subsection{Asset Protection at the Supreme Court}

Assets in government management are owned by the government and include other assets controlled by the government in the framework of services or the implementation of government duties and functions. Regional asset management must be handled properly so that the investment can be the government's initial capital to develop its financial capabilities. However, if not managed properly, the asset becomes a cost burden because part of the support requires maintenance or maintenance costs and decreases in value (depreciates) over time.

Besides, State Property will generally include in the financial statements, especially in the government balance sheet, which, if not managed effectively and efficiently, will cause irregularities and misappropriation will harm the institution. Good governance in the government element is not carried out. To support good governance, the management of stateowned goods must be carried out properly, starting at the time of planning and budgeting of state-owned goods to the administration of property itself.

According to Sholeh and Rohmatsyah (2010), simple management of State Property includes 3 (three) main functions, namely: (1) The existence of proper planning, (2) efficient and effective implementation/utilization and (3) monitoring. These three main functions are 
demonstrated in the cycle of management of State Property. For these three functions to be achieved, a strategy is needed in bmn management. Strategic objectives that must be achieved through management, among others, (1) the realization of administrative order on regional wealth both concerning the inventory of land and or buildings, certification of regional assets, the elimination and sale of state assets, the reporting system of exchange activities, grants and ruislag, (2) the creation of efficiency and effectiveness of the use of regional holdings in supporting development activities, (3) securing regional assets and (4) the availability of accurate data and information on the wealth (assets) of MA.

Article 1 of Law No. 17 of 2003 on State Finance implies that state finances not only include state matters and obligations that can be assessed directly with money but also include everything in the form of goods that can be made state property in connection with the exercise of such rights and obligations. If withdrawn at a lower level to the region, then the content of Article 1 of Law No. 17/2003 can be interpreted that regional finances also include rights and obligations related to state-owned goods.

Furthermore, Law No. 1 of 2004 on State Treasury explicitly states that reforms in the field of state finance include reforms in the management of state property. This understanding can be concluded that State Property is an integral part of the Supreme Court's Finances and therefore required a legal umbrella governing the regional property's management. In this case, the Government Regulation and its implementing regulations are the legal umbrellas in question. Further explained that regional property management is a series of activities and actions against State Property stipulated by Government Regulations guided by applicable laws and regulations.

\section{Conclusion}

To implement the drafting of the Regulation of the Minister of Finance on State Property to be appropriately implemented, a transparent mechanism and procedures are required under the prevailing laws and regulations. The broad scope of material content that regulation in this Regulation of the Minister of Finance includes provisions on planning needs and budgeting, procurement, use, utilization, security and maintenance, assessment, transfer, destruction, elimination, administration and construction, supervision and control of State Property. This Regulation of the Minister of Finance on State Property is necessary to secure State Property, Homogenize measures and actions in the management of State Property, and provide guarantees or legal certainty in State Property's direction in the Supreme Court. Administration of State Property of the Supreme Court refers to Government Regulation No. 27 of 2014 and other related laws and regulations.

\section{References}

[1] Ardita, Mikho. 2020. "Tanggung Jawab Negara Terhadap Jaminan Kesehatan Dalam Perspektif Hak Asasi Manusia." Jurnal HAM 11(2): 319-33.

[2] Christasani, Putu Dyana, and Satibi Satibi. 2016. "Kajian Faktor Demografi Terhadap Kepuasan Pasien Jaminan Kesehatan Nasional Pada Fasilitas Kesehatan Tingkat Pertama." Journal of Pharmaceutical Sciences and Community 13(01): 28-34. 
[3] Dahliana, Anita. 2019. "Motivasi Kepesertaan Mandiri BPJS Di Era Universal Health Coverage Jaminan Kesehatan Nasional." KELUWIH: Jurnal Kesehatan dan Kedokteran 1(1): 11-18.

[4] Djasri, Hanevi, Puti Aulia Rahma, and Eva Tirtabayu Hasri. 2016. "Korupsi Dalam Pelayanan Kesehatan Di Era Jaminan Kesehatan Nasional: Kajian Besarnya Potensi Dan Sistem Pengendalian Fraud." Integritas 2(1): 113-33. https://acch.kpk.go.id/id/component/content/article?id=672:korupsi-dalam-pelayanankesehatan-di-era-jaminan-kesehatan-nasional-kajian-besarnya-potensi-dan-sistempengendalian-fraud.

[5] Geswar, Rezky Kurnia, and Nurhayani Balqis. 2014. "Kesiapan Stakeholder Dalam Pelaksanaan Program Jaminan Kesehatan Nasional Di Kabupaten Gowa.” Jurnal AKK 3(1): 1-12.

[6] Karim, Muhammad Imanuddin Taqwa, A. Pangerang Moenta, and Marwati Riza. 2018. "Implementasi Kebijakan Pemerintah Daerah Di Bidang Kesehatan Masyarakat Melalui Jaminan Kesehatan Nasional.” Amanna gappa 26(1): 53-63.

[7] Sudrajat, Tedi, Siti Kunarti, and Abdul Aziz Nasihuddin. 2020. "Perlindungan Hukum Dan Pemenuhan Hak Pekerja Pada Program Jaminan Kesehatan Nasional.” Pandecta Research Law Journal 15(1): 83-92.

[8] Supriyanto, Eko Eddya. 2020. Eksistensi Nilai-Nilai Pancasila Dalam Kebijakan Ekonomi Indonesia. 1st ed. Malang: Literasi Nusantara.

[9] Thabrany, Hasbullah. 2009. "Badan Penyelenggara Jaminan Kesehatan Nasional: Sebuah Policy Paper Dalam Analisis Kesesuaian Tujuan Dan Struktur BPJS." Universitas Indonesia: 1-47. https://staff.ui.ac.id/system/files/users/hasbulah/material/bpjsnsionalataubpjsd.pdf\%0A Accessed: 2020-11-01.

[10] Yudiana, I Gede, Novita Listyaningrum, and Nuraini Dwi. 2020. "Perlindungan Hukum Bagi Pasien Pengguna Badan Penyelenggara Jaminan Sosial (BPJS) Di Rumah Sakit Kota Mataram.” Binawaya 14(12): 3591-3602.

[11] Yuniar, Yuyun, and Rini Sasanti Handayani. 2016. "Kepuasan Pasien Peserta Program Jaminan Kesehatan Nasional Terhadap Pelayanan Kefarmasian Di Apotek The Satisfaction of National Health Insurance P Rogram's Patients On Pharmaceutical Services in Pharmacy ( JKN ) Adalah Program Jaminan Berupa Bentuk Pel.” Jurnal Kefarmasian Indonesia 6(1): 39-48. 